\title{
Evaluation of DAPG - Producing Fluorescent Pseudomonas for Enhancing Nutrient Use Efficiency, Bio-Control of Soil Borne Diseases and Yield of Groundnut
}

\author{
A.H. Kumar Naik $^{1 *}$, N. Pallavi ${ }^{1}$ and N.E. Naveen ${ }^{2}$ \\ ${ }^{1}$ All India Coordinated Research Project on Groundnut, Zonal Agricultural and \\ Horticultural Research Station, Babbur Farm, Hiriyur, Karnataka 577 598, India \\ ${ }^{2}$ Scientist, Krushi Vigyan Kendra, Brahmavar, Karnataka, India \\ *Corresponding author
}

\begin{abstract}
Keywords
DAPG,

Pseudomonas spp.,

Bio-control,

Groundnut.

Article Info

Accepted:

04 September 2017

Available Online:

10 October 2017 nutrition and constant exposure to both biotic and abiotic stress factors. Therefore, it is most essential to pay a great attention towards the nutrition of groundnut to enhance its productivity. In this regard an experiment was conducted at Zonal Agricultural and Horticultural Research Station, Hiriyur, Chitradurga district, during Kharif 2015-16. Experiment was laid out in a Randomized Complete Block Design (RCBD) with four replications and 7 treatments to understand the efficacy of antibiotic 2,4diacetylphloroglucinol (DAPG), produced by some strains of Pseudomonas spp., which may be involved in suppression of several fungal root pathogens and play a beneficial role in plant growth and development along with bio-control activities. The results revealed that majority of the cultures inoculated resulted in enhancement yield attributing traits compare to control. DAPG-1 significantly enhanced the pod yield of $25 \%$ over control and DAPG-2 were on par with DAPG-1 (2587 kg/ha pod yield). There were 10 and $15 \%$ increase in pod yield of FP-86 and FP- 98 respectively as compared to control. Incidence of root rot was also recorded at 60 and 120 days periodically, After 60 days of sowing, significant differences were observed in the incidence among the treatments. The disease incidence in the treatments was below 6\% (FP-98 and DAPG-1 \& 2) as compared to control 8.4\%. DAPG 2 recorded the lowest incidence (4.6\%). After 120 days fewer incidences was recorded in DAPG-2 (8.1\%) as compared to control.
\end{abstract}

A B S T R A C T

Groundnut (Arachis hypogaea L.) most versatile legume and an important oilseed crop in the tropics and semi-arid tropics and its estimated annual production in India is around 6.0 million tones which contributes nearly $30 \%$ of the domestic edible oil production. Yield and quality of oil in groundnut is sizeable dependent on proper application of different nutrients that have a direct say on yield traits. Low productivity of groundnut in Karnataka could be attributed to several production constraints, which include poor or imbalanced

\section{Introduction}

Groundnut is called as 'King' of oilseeds and one of the most important food and cash crops of our country. It's grown over an area of53.21 lakh ha, with an annual production of
84.72 lakh tonnes with a productivity of 1592 $\mathrm{kg} \mathrm{ha}^{-1}$. In Karnataka, its area is 6.63 lakh ha and production of 4.54 lakh tonnes and average productivity is $\left(685 \mathrm{~kg} \mathrm{ha}^{-1}\right)$. Yield 
and quality of oil in groundnut is negatively correlated with poor or imbalanced nutrition and constant exposure to both biotic and abiotic stress factors. Variety of diseases affect groundnut plant, most them are caused by fungi and lead to severe yield loss (Ganesan et al., 2007) which forces plants to adopt new sustainable methods, such as the use of microbial antagonists, for the control of soil borne pathogens. Indiscriminate use of chemical fertilizers increases the concerns of environmental deterioration along with indirect effects on human and animal health. Among different microbial antagonists, Pseudomonas is common members of the plant growth-promoting rhizobacterial microflora present in rhizosphere of groundnut. These are more beneficial in production and survival of plants due to their high metabolic activity (i.e. production of enzymes, exopolysaccharides, secondary metabolites, antibiotics, etc.).The ability of pseudomonas to suppress soil-borne fungal pathogens depends on their ability to produce antibiotic metabolites, such as pyoluteorin, pyrrolnitrin, phenazine-1-carboxylic acid, 2, 4-diacetylphloroglucinol (DAPG) (Troppens et al., 2013). productivity of groundnut can be enhanced by sustainable application of an Antibiotic 2,4-diacetylphloroglucinol (DAPG), which can inhibit the growth and/or activities of several fungal and oomycete root pathogens (Raaijmakers et al., 2002), which also increases the availability of plant nutrients (Nutrient use efficiency) and provides protection against plant pathogenic fungi by inhabiting roots which affect plant growth promotion by mechanisms ranging from a direct influence such as increased solubilization and uptake of nutrients. (Richardson et al., 2009; Mantelin and Touraine 2004). DAPG is active against numerous organisms, including plants, fungi, viruses, bacteria and nematodes. Increased production of DAPG has been associated with enhanced activity against plant pathogens
(Dwivedi and Johri, 2003; Siddiqui and Shaukat, 2004). Consequently application of DAPG producing pseudomonas can result in increased crop yields (Mcspadden Gardener et al., 2006).

This paper documents the results of bioefficacy of DAPG - producing Fluorescent pseudomonas for enhancing nutrient use efficiency and bio-control of soil borne diseases by increasing yield of groundnut.

\section{Materials and Methods}

Field experiments were carried out during the Kharif seasons 2015-16 at Zonal Agricultural and Horticultural Research Station, Hiriyur, to evaluate potentiality of DAPG - producing Fluorescent pseudomonas and Trichoderma species for enhancing nutrient use efficiency, bio-control of soil borne diseases and yield of groundnut. The experimental site showed medium red to black soil, slightly saline in $\mathrm{pH}$, medium in organic carbon $(>0.75 \%)$, varied available nitrogen (280-560 $\left.\mathrm{N} \mathrm{ha}^{-1}\right)$, low in available phosphorus $\left(<22 \mathrm{Kg} \mathrm{P}_{2} \mathrm{O}_{5}\right.$ ha ${ }^{1}$ ) and available potassium ( $>299 \mathrm{Kg} \mathrm{K}_{2} \mathrm{O}$ ha $\left.{ }^{1}\right)$. An experiment consists of 7 treatments and as follows: T1: Control, T2: DAPG-1, T3: DAPG-2. T4: DAPG-4, T5: FP 86, T6: FP 98, T7: Trichoderma sp. All the treatments were treated with seeds through jaggery in chalka type soils using groundnut cv. KCG6. The experiment was laid out in a Randomized Complete Block Design (RCBD), at three replications of different treatments of groundnut with recommended dose of fertilizers with plot size of $5.0 \times 4.5 \mathrm{~m}$ and spacing of (between rows) x $10 \mathrm{~cm}$ (plant to plant).The data on germination percentages was recorded after 2 weeks of sowing and also the incidence of root rot was recorded at 60 and 120 days after sowing (DAS). At the time of harvest, five representative plants were collected randomly from each treated plots to asses few growth parameters like 
plant height $(\mathrm{cm})$, shoot length $(\mathrm{cm})$, root length $(\mathrm{cm})$, no of pods/plant, 100 seed weight $(\mathrm{g})$, shelling percentage $(\%)$, Percent root rot at 60 and 120 DAS and pod yield $(\mathrm{Kg} / \mathrm{ha})$ etc., All the data on growth, yield and other yield attributes were analyzed statistically.

\section{Results and Discussion}

DAPG- producing fluorescent pseudomonas was evaluated on groundnut cv. KCG -6. During Kharif- 2015, present investigation, revealed that the majority of the cultures inoculated (DAPG-1, 2, 4, and FP-86, 98) resulted in enhancement of haulm yield and kernel yield. Promotion of these yield parameter led to augmentation of pod yield; DAPG-1 significantly enhanced the pod yield of $25 \%$ over un-inoculated control and DAPG-2 and 4 (25\% increase in yield over control) were on par with DAPG-1 (2587 $\mathrm{kg} / \mathrm{ha}$ pod yield). There were 10 and $15 \%$ increase in pod yield of FP-86 and FP- 98 respectively as compared to control. Incidence of root rot was recorded at 60 and 120 days periodically, After 60 days of sowing, significant differences in the incidence among the treatments were observed. The disease incidence in the treatments was below $6 \%$ (FP-98 and DAPG$1 \& 2$ ) as compared to control $8.4 \%$. DAPG 2 recorded the lowest incidence (4.6\%). After 120 days fewer incidences was recorded in DAPG-2 $(8.1 \%)$ as compared to control (Table 1).

Fluorescent pseudomonades are among the most effective rhizospheric bacteria used to suppress diseases caused by soil-borne plant pathogens. P. fluorescens has been reported to be effective against Fusarium oxysporum infecting in tomato (Benhamou et al., 1996).

Weller et al., (2002) have shown that 2, 4diacetylpholoroglucinol (DAPG) producing fluorescent pseudomonas play a key role in declining the population of the pathogens (Raajimakers et al., 1998 and 2001). Production of the antibiotic 2, 4-DAPG contributes to biological control activity of many beneficial strains of the bacterium $P$. fluorescens (McSpadden Gardener, 2007; Weller, 2007).
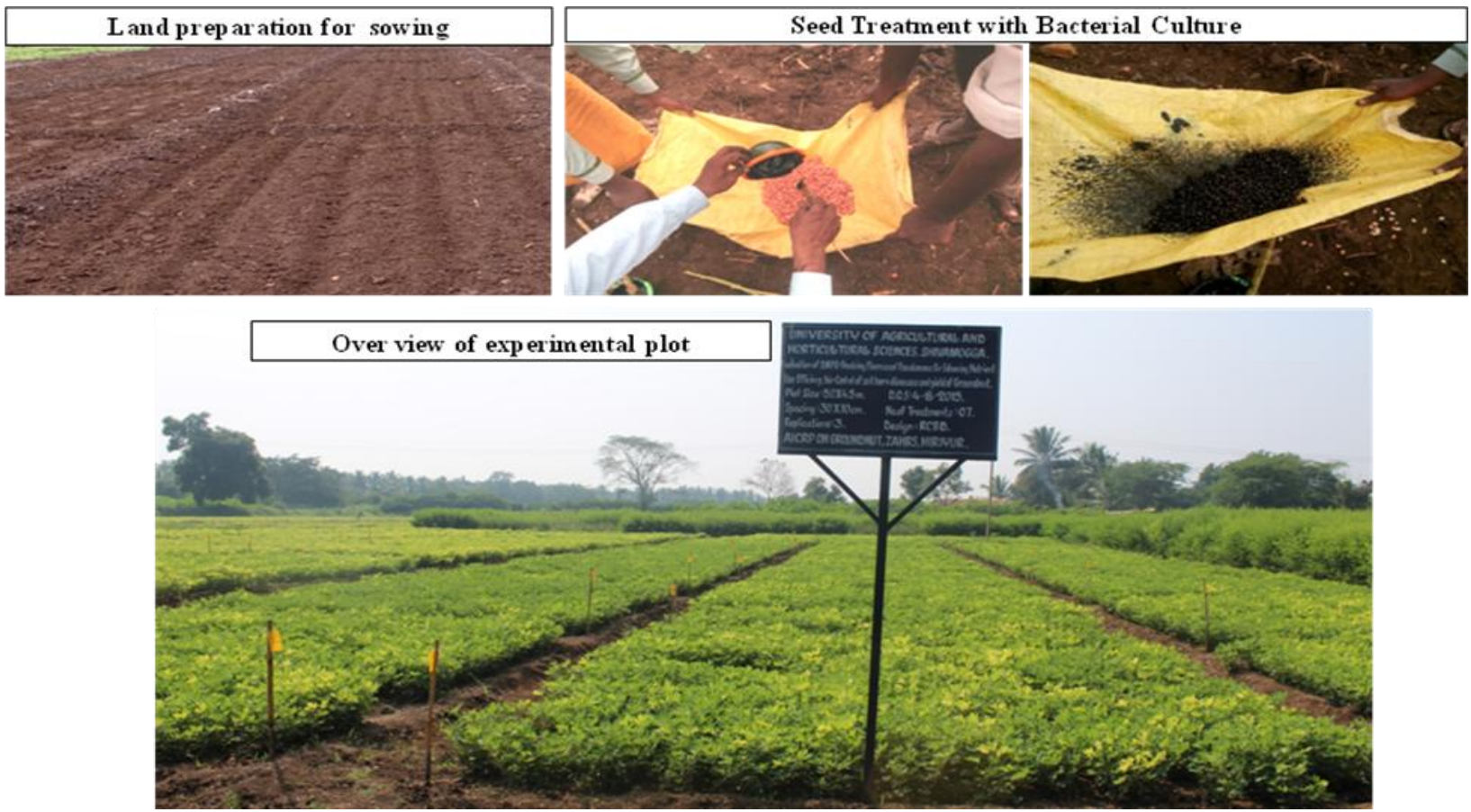
Table.1 Yield attributing traits as influenced by different biological strains in Groundnut experiment

\begin{tabular}{|c|c|c|c|c|c|c|c|c|c|c|c|c|}
\hline \multicolumn{2}{|c|}{ Treatments } & $\begin{array}{l}\text { Initial } \\
\text { plant } \\
\text { stand }\end{array}$ & $\begin{array}{l}50 \% \\
\text { flowe } \\
\text { ring }\end{array}$ & $\begin{array}{l}\text { Plant } \\
\text { Height }\end{array}$ & $\begin{array}{l}\text { No. of } \\
\text { Pods/ } \\
\text { Plant }\end{array}$ & $\begin{array}{l}100 \\
\text { seed } \\
\text { weigh } \\
\mathrm{t}(\mathrm{g}) \\
\end{array}$ & $\begin{array}{l}\% \text { Root } \\
\text { rot at } \\
60 \\
\text { DAS }\end{array}$ & $\begin{array}{l}\% \text { Root } \\
\text { rot at } \\
120 \\
\text { DAS } \\
\end{array}$ & $\begin{array}{l}\text { Shelling } \\
\%\end{array}$ & $\begin{array}{l}\text { Kernel } \\
\text { Yield/ } \\
\text { ha }\end{array}$ & $\begin{array}{l}\text { Pod } \\
\text { Yield } \\
\text { (kg/ } \\
\text { ha) } \\
\end{array}$ & $\begin{array}{l}\text { Haul } \\
\text { m } \\
\text { Yield/ } \\
\text { ha }\end{array}$ \\
\hline $\mathrm{T}-1$ & Control & 346 & 29 & 41.1 & 24 & 27.8 & 8.4 & 11.1 & 73 & 1407 & 1925 & 1592 \\
\hline $\mathrm{T}-2$ & DAPG 1 & 359 & 31 & 50.4 & 35 & 32.3 & 5.9 & 8.7 & 77 & 2005 & 2587 & 2001 \\
\hline $\mathrm{T}-3$ & DAPG 2 & 363 & 31 & 46.9 & 31 & 28.1 & 4.6 & 8.1 & 75 & 1932 & 2582 & 2138 \\
\hline $\mathrm{T}-4$ & DAPG 4 & 336 & 30 & 45.2 & 33 & 29.9 & 8.2 & 10.8 & 76 & 1940 & 2560 & 1983 \\
\hline $\mathrm{T}-5$ & FP 86 & 372 & 30 & 46.5 & 26 & 29.8 & 6.3 & 10.6 & 76 & 1623 & 2142 & 1854 \\
\hline T-6 & FP 98 & 347 & 29 & 44.3 & 28 & 30.1 & 5.1 & 8.2 & 76 & 1724 & 2272 & 2007 \\
\hline \multirow[t]{3}{*}{$\mathrm{T}-7$} & Trichoderma spp. & 345 & 29 & 42.9 & 25 & 31.9 & 6.6 & 9.0 & 77 & 1619 & 2109 & 1635 \\
\hline & SEm \pm & 23.6 & 0.4 & 2.1 & 2.3 & 1.64 & 0.70 & 0.7 & 189 & 109 & 145 & 187 \\
\hline & $\mathrm{CD}(\mathrm{P}=0.05)$ & 72.9 & 1.3 & 6.7 & 7.2 & 5.04 & 2.16 & 2.2 & 582 & 338 & 447 & 577 \\
\hline
\end{tabular}

Hence treatment with DAPG reduced root rot incidence and increased pod yield considerably. Based on this study it is concluded that a simple seed treatment with potential antagonists during sowing would reduce the incidence of root rot and improve the yield in groundnut drastically.

From the above investigations it can be inferred that Chemicals are not ultimate alternative methods to control many diseases, as they potentially cause negative impact on ecosystem. Seed treatment adopted through different biological control agents was found superior in enhancing yield and nitrogen use efficiency in groundnut with lesser diseases incidence also responsible to increase productivity of groundnut as it requires higher amount of nutrients during pegging and pod development stages.

\section{Acknowledgement}

The authors would like to thank the Directorate of Groundnut Research, Indian council of agricultural research station, Junagadh, Gujarat, India, and also Zonal Agricultural and Horticultural research station, Hiriyur, Chitradurga District, for facilitating these trials.

\section{References}

Benhamou, N., Belanger, R. R. and Paulitz, T. C. 1996. Induction of differential host responses by Pseudomonas fluorescence and $\mathrm{Ri}$ T-DNA transformed pea roots upon challenge with Fusarium oxysporum f. Sp. Pisi and Pythium ultimum. Phytopathology, 86: 1174-1185.

Dwivedi, D., and Johri, B. N. 2003. Antifungals from fluorescent pseudomonads: biosysnthesis and regulation. Current Science, 85: 1693:1703.

Ganesan, S., Ganesh Kuppusamy, R. and Sekar, R. 2007. Integrated management of stem rots disease (Sclerotium rolfsii) of groundnut (Arachis hypogea L.) using Rhizobium and Trichoderma harzianum (ITCC-4572). Turkish Journal of Agriculture and Forestry, 31: 103-108.

Mantelin, S., and Touraine, B. 2004. Plant growth-promoting bacteria and nitrate availability: impacts on root development and nitrate uptake. J. Exp. Bot., 55: 27-34.

McSpadden Gardener, B., 2007. Diversity and ecology of bio-control Pseudomonas in 
agricultural systems. Phytopathology, 97: 21-226.

McSpadden Gardener, B., Kroon van Diest, C., and Beuerlein, J. 2006. Evaluation of biological seed treatment containing aphlD + strain of Pseudomonas fluorescens on soybeans grown in Ohio, 2005. Biological and Cultural Tests for Control of Plant Diseases Report21: FC045.

Raaijmakers, J. M., Vlami, M. and de Souza, J. T., 2002. Antibiotic production by bacterial bio-control agents. Antonie Van Leeuwenhoek Suppression of nematodes by Pseudomonas fluorescence: International Journal of General and Molecular Microbiology, 81: 537-547.

Raajimakers, J. M., and Weller, D. M. 1998. Natural plant protection by 2, 4diacetylphloroglucinol-producing

Pseudomonas spp. in take all decline soils. Mol. Plant- Microbe Interaction, 11: 144-152.

Richardson, A.E., Barea J., McNeill A.M. and Prigent-Combaret, $\quad$ C., 2009. Acquisition of phosphorus and nitrogen in the rhizosphere and plant growth promotion by microorganisms. Plant Soil, 321: 305-339.

Siddiqui, I. A., and Shaukat, S. S., 2004. Suppression of Meloidogyne incognita by Pseudomonas fluorescence strain $\mathrm{CHAO}$ and its genetically-modified derivatives: II. The influence of sodium chloride. Nematologia Mediterranea, 32: $127-130$.

Troppens, D.M., Dmitriev, R.I., Papkovsky, D.B., O'Gara, F. and Morrissey, J.P., 2013. Genome- wide investigation of cellular targets and mode of action of antifungal bacterial metabolite 2, 4diacetylphloglucinol in Saccharomyces cerevisiae. FEMS Yeast Res., 13: 322334

Weller, D. M., 2007. Pseudomonas biocontrol agents of soilborne pathogens: Looking back over 30 years. Phytopathology, 97: 250-256.

Weller, D.M., Raaijmakers, J.M., Gardener, B.B.M. and Thomashow, L.S. 2002. Microbial populations responsible for specific soil suppressiveness to plant pathogens. Annu. Rev. Phytopathol., 40: 309-348.

\section{How to cite this article:}

Kumar Naik, A.H., N. Pallavi and Naveen, N.E. 2017. Evaluation of DAPG - Producing Fluorescent Pseudomonas for Enhancing Nutrient Use Efficiency, Bio-Control of Soil Borne Diseases and Yield of Groundnut. Int.J.Curr.Microbiol.App.Sci. 6(10): 246-250. doi: https://doi.org/10.20546/ijcmas.2017.610.030 